\title{
SALT STRESS EFFECTS IN THE PHYSIOLOGICAL QUALITY OF CAJANUS CAJAN (L.) MILLSPAUGH SEEDS AT DIFFERENT TEMPERATURES
}

\author{
Edlânia Maria de Souza*1, Maria Lúcia Maurício da Silva², Edna Ursulino Alves², Maria das \\ Graças Rodrigues do Nascimento², Rosemere dos Santos Silva ${ }^{2}$ \\ e Raquel Maria de Oliveira Pires ${ }^{1}$
}

${ }^{1}$ Departamento de Agricultura, Universidade Federal de Lavras, Lavras/MG, 37200-000, Brasil; ${ }^{2}$ Departamento de Fitotecnia e Ciências Ambientais, Centro de Ciências Agrárias, Campus II da Universidade Federal da Paraíba. Rodovia PB-079, km 12, Areia/PB, 58397-000, Brasil

\section{ARTICLE INFO}

Article History:

Received $11^{\text {th }}$ February, 2021

Received in revised form

$22^{\text {nd }}$ March, 2021

Accepted $17^{\text {th }}$ April, 2021

Published online $30^{\text {th }}$ May, 2021

Key Words:

Pigeon pea. Abiotic stress.

Vigor. $\mathrm{NaCl}$.

\begin{abstract}
Cajanus cajan (L.) Millspaugh, known as pigeon pea, is considered a rustic legume, hightemperature tolerant, well adapted to environments with low water availability, saline, and low fertility soils. This study aimed to evaluate the germination and vigor of Cajanus cajan seeds under conditions of salt stress and different temperatures. A completely randomized experimental design was used, with treatments distributed in a $6 \times 3$ factorial scheme (salinity levels and temperatures), with four replications of 50 seeds. After determining the seed water content, the seeds were placed on germitest paper moistened with sodium chloride $(\mathrm{NaCl})$ solutions in concentrations of 0.0 (control); $2.0 ; 4.0 ; 6.0 ; 8.0$ and $10.0 \mathrm{dS} \mathrm{m}^{-1}$; Seeds were incubated in a B.O.D, at constant temperatures of 25 and $30{ }^{\circ} \mathrm{C}$ and alternating $20-30{ }^{\circ} \mathrm{C}$. The germination and vigor tests (first germination count, germination speed index, length and dry mass of roots and shots) were evaluated. An interaction between the salt concentration and temperature for all variables analyzed was observed, with a negative effect on the germination and vigor of Cajanus cajan seeds as the salinity levels increased. Salt stress simulated with $\mathrm{NaCl}$ reduced the germination and vigor of Cajanus cajan seeds, mainly when submitted to the temperature of 25 ${ }^{\circ} \mathrm{C}$. However, the increase in $\mathrm{NaCl}$ concentration, up to the potential $10.0 \mathrm{dS} \mathrm{m}^{-1}$, was not high enough to impair seed germination.
\end{abstract}

*Corresponding author:

Edlânia Maria de Souza

This is an open access article distributed under the Creative Commons Attribution License, which permits

Copyright (C) 2021, Edlânia Maria de Souza et al. This is an open access article distributed under the Creative Commons Attribution License, which permits unrestricted use, distribution, and reproduction in any medium, provided the original work is properly cited.

Citation: Edlânia Maria de Souza, Maria Lúcia Maurício da Silva, Edna Ursulino Alves, Maria das Graças Rodrigues do Nascimento, Rosemere dos Santos Silva e Raquel Maria de Oliveira Pires, 2021. "Salt stress effects in the physiological quality of Cajanus cajan (L.) millspaugh seeds at different temperatures", International Journal of Development Research, 11, (05), 47289-47294.

\section{INTRODUCTION}

The Pigeon pea [Cajanus cajan(L.) Millspaugh], is an annual or semi-perennial shrub of the Fabaceae family and subfamily Faboideae (SANTOS, 2000), this plant species can grow up to four meters height, with significant economic importance for many countries, especially in the Asian and African continent, where it is largely cultivated, and considered as staple food (AZEVEDO et al., 2007). However, the origin of the Cajanus cajan species is not clear and diverges between the African continent and India (NENE; SHEILA, 1990). This crop is widely used for different purposes, such as soil quality improvement, recovery of degraded areas, phytoremediation, pasture renewing in the form of forage, in addition to the consumption of its grains on a large scale (AZEVEDO et al., 2007). In Brazil, Cajanus cajan is a good alternative for the familybased agricultural system, especially in the Brazilian semiarid region, considering its good adaptation to the climatic conditions of this region (AZEVEDO et al., 2007), given its rusticity, high-temperature tolerance, making it suitable to production in areas with low water availability, saline, and low fertility soils (RUFINI et al., 2014). The high concentration of salts in the soil is a major concern in arid and semi-arid regions, given its adverse effects on plant development and agricultural production (TAYYAB et al., 2016). In these regions, evapotranspiration is higher than precipitation and, it prevents water percolation along with the soil profile, thus causing salt leaching on the soil surface (FREIRE; FREIRE, 2007). Under laboratory conditions, it is possible to simulate salt stress for seed germination with osmotic agents, such as calcium chloride $\left(\mathrm{CaCl}_{2}\right)$ and sodium chloride $(\mathrm{NaCl})$ (PELEGRINI et al., 2013). The high concentration of salts is a major problem for seed germination since it is a stress factor for plants, hindering water absorption and increasing ions concentration in the protoplasm (AMORIM et al., 2002). This negatively affects plant growth and induces modifications in its 
morphology and structure. In addition to soil salinity, the temperature is an environmental factor of significant influence on the seed germination process, affecting both the percentage and speed of germination due to the water absorption speed and the biochemical reactions that determine the entire process. Thus, the higher the temperature, up to a certain limit, the faster will be the germination and efficient the process (CARVALHO; NAKAGAWA, 2012). The salt stress and temperature effect on seed germination and vigor are intensively studied in agricultural and forest species. In a study with lima beans (Phaseolus lunatus L.), Nascimento et al. (2017) observed that the salt stress simulated with $\mathrm{NaCl}$ did not interfere in the germination process of the seeds until up to the concentration of 9.0 $\mathrm{dS} \mathrm{m}^{-1}$. However, at the temperature of $35{ }^{\circ} \mathrm{C}$, the seedling development was impaired. The negative effect of salinity was also evidenced in studies on other species, such as soybean (Glycine $\max$ L.) (SOARES et al., 2015), green beans (Phaseolus vulgaris L.) (GOMES; ALMEIDA; TAKAHASHI, 2015), cowpea (Vigna unguiculata (L.) Walp.) (ARAÚJO NETO et al., 2020) and maize (Zea mays L.) (ALMEIDA et al., 2020). The germination and vigor of the sombrero forest species (Clitoria fairchildiana Howard) were affected by salinity increase, with a slight decrease effect at $25{ }^{\circ} \mathrm{C}$ (SILVA et al., 2019). Araújo, Moreira, and Guedes (2019) evaluated the emergence and initial growth of Cajanus cajan seedlings cultivar 'BRS Mandarim', on substrates and water salinity levels at $30{ }^{\circ} \mathrm{C}$ and obtained normal seedling emergence up to the salinity level of $3.0 \mathrm{dS}$ $\mathrm{m}^{-1}$. Differently, in studies with catingueira seeds (Cenostigma pyramidale (Tul.) Gagnon \& G.P. Lewis), Matias et al. (2018) observed that the salinity levels did not interfere in the germination process of the seeds up to $-0.6 \mathrm{MPa}$, at temperatures of 25,30 and 20$40{ }^{\circ} \mathrm{C}$. Therefore, this study aimed to evaluate the effect of salt stress on the germination and vigor of Cajanus cajan seeds at different temperatures.

\section{MATERIALS AND METHODS}

The experiment was carried out at the Seed Analysis Laboratory of the Centro de Ciências Agrárias, Universidade Federal da Paraíba, Areia, PB, Brazil. The fruits (pods) of Cajanus cajan were harvested dry on the crown of the parent plants, located in the municipality of Alagoa Nova, PB, Brazil (Latitude: $7^{\circ} 4$ ' 5 ' 'South, Longitude: $35^{\circ}$ $45^{\prime} 40$ " West). The pods were manually threshed to obtain the seeds. Sodium chloride $(\mathrm{NaCl})$ was used to simulate the salt stress in the following concentrations: 0.0 (control); $2.0 ; 4.0 ; 6.0 ; 8.0$ and $10.0 \mathrm{dS}$ $\mathrm{m}^{-1}$, diluted in distilled and deionized water. The electrical conductivity of the solutions was obtained according to Richards (1954) methodology and verified with a conductivity meter. For control $\left(0.0 \mathrm{dS} \mathrm{m}^{-1}\right)$, only distilled and deionized water was used to moisten the substrate. The following tests and determinations were performed:

Water content - Determined by the greenhouse method at $105 \pm 3^{\circ}$ $\mathrm{C}$ for 24 hours, according to the Rules for Seed Analysis (BRASIL, 2009), with four replications of 10 seeds.

Germination test - Seeds were previously treated with the fungicide Captan $^{\circledR}$ at a concentration of $240 \mathrm{~g} .100 \mathrm{~kg}^{-1}$ of seeds, divided into four replications of 50 seeds, totaling 200 seeds per treatment, distributed on two sheets of germitest paper, covered with a third layer and arranged in the form of a roll. The germitest paper was previously moistened with $\mathrm{NaCl}$ solutions at the concentrations mentioned above with a volume equivalent to 3.0 times the dry paper weight (SOUZA et al., 2017).

The paper rollers were placed in transparent plastic bags, closed with rubber ties to prevent water loss, and incubated in B.O.D. (Biological Oxygen Demand) regulated at constant temperatures of 25 and $30{ }^{\circ} \mathrm{C}$ and alternating at $20-30{ }^{\circ} \mathrm{C}$, with 16 hours of light photoperiod, using daylight fluorescent lamps ( $4 \times 20 \mathrm{~W})$. The evaluations to determine the germination percentage were carried out daily, from the third to the seventh day after the test setup. At the end of the experiment, seeds with primary root and aerial part present were considered germinated (normal seedlings), according to Brazil recommendations (2009).

First germination count - determined together with the germination test by counting the number of normal seedlings (root and shoot present) on the third day after the experiment setup, with results expressed as a percentage.

Germination speed index (GSI) - the counts of the germinated seeds were carried out daily, at the same time, from the third to the seventh day after the experiment setup, with the germination speed index (GSI) using the formula proposed by Maguire (1962).

Root and shoot length - at the end of the germination test, all normal seedlings of each treatment and replication were measured (root and shoots, individually) with a centimeter graduated ruler.

Root and shoot dry mass - after measured, roots and shoots of the seedlings were placed, individually, in kraft paper bags and placed in a forced air circulation oven at $65^{\circ} \mathrm{C}$ for 48 hours. After this period, the samples were weighed on an analytical scale ( $0.001 \mathrm{~g}$ accuracy) with results expressed in g.plantula ${ }^{-1}$.

A completely randomized experimental design was used, in a $6 \times 3$ factorial scheme (salt concentrations $x$ temperatures), with the treatments distributed in four replications of 50 seeds. Data were submitted to analysis of variance and polynomial regression. Data were fitted to linear and quadratic models and selected the model with the greatest $\mathrm{R}^{2}$. The Scott-Knott test compared the means at 5\% probability. The statistical software SISVAR was used for all analyses (FERREIRA, 2000).

\section{RESULTS AND DISCUSSION}

The Cajanus cajan seeds had $12.18 \%$ water content at the beginning of the experiment. For all the variables analyzed, a significant interaction was observed between salt concentration and temperature. The seeds germination was affected by the increasing salinity concentration in the different temperatures, with the highest percentages of germination (72 and $84 \%$ ) observed in control ( $0.0 \mathrm{dS}$ $\left.\mathrm{m}^{-1}\right)$, with subsequent linear decrease for seeds submitted to temperatures of 25 and $30{ }^{\circ} \mathrm{C}$, respectively. A higher percentage of germination $(84 \%)$ was observed in the saline concentration of $2.0 \mathrm{dS}$ $\mathrm{m}^{-1}$ at $20-30{ }^{\circ} \mathrm{C}$, with a significant decrease to $64 \%$, in the salinity level of $10.0 \mathrm{dS} \mathrm{m}^{-1}$ (Figure 1).

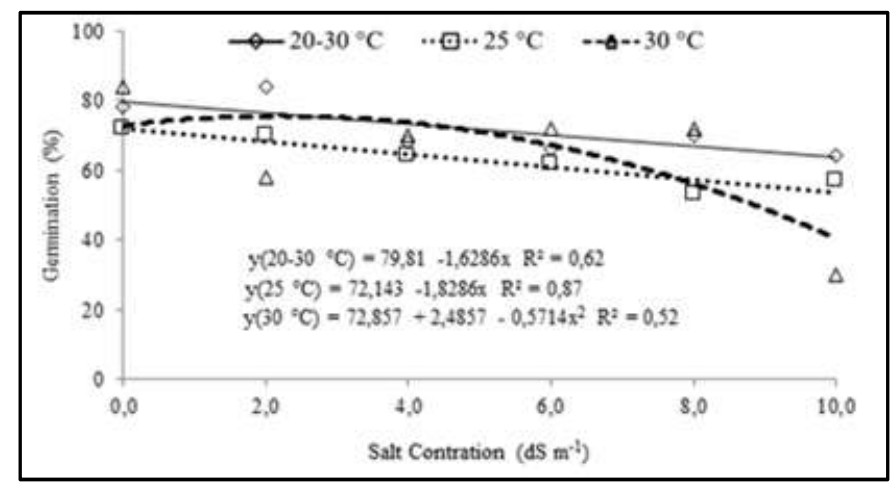

Figure 1. Germination (\%) of Cajanus cajan (L.) Millspaugh seeds submitted to salt stress at different temperatures

The germination decreases of Cajanus cajan seeds occurred due to the increase in salt concentration, which probably caused toxicity conditions due to ions accumulation, causing physiological and biochemical disturbances, such as decreased reserves use and hormonal imbalance (PEREIRA et al., 2017). In addition, the presence of salts may have affected the water potential of the substrate, decreasing the potential between the substrate and the seed surface, limiting water absorption, consequently reducing 
germination (LOPES; MACEDO, 2008). Although the increasing salinity affected the germination process, the germination percentage remained high, indicating that the saline concentrations were not high enough to inhibit their germination. In addition, seed germination is one of the least affected stages by saline environments during plant development (COELHO et al., 2010). In a study by Araújo, Moreira, and Guedes (2019), the emergence and initial growth of Cajanus cajan seedlings cultivar 'BRS Mandarim' was evaluated in function of substrates and water irrigation salinity levels at $30{ }^{\circ} \mathrm{C}$, and they observed that the percentage of emergence reduced as the salinity increased from 0.27 to $6.0 \mathrm{dS} \mathrm{m}^{-1}$. Similarly, Soares et al. (2015) found a decrease in the germination of Glycine max seeds as the salinity increased. Figure 2, shows the first germination count of Cajanus cajan seeds. A germination percentage of $79 \%$ was obtained in the control treatment $\left.(0.0 \mathrm{dS} \mathrm{m})^{-1}\right)$ at the alternating temperature of $20-30{ }^{\circ} \mathrm{C}$. The seed germination percentage in the first count decreased to $57 \%$, as the salinity increased until up to $10.0 \mathrm{dS}$ $\mathrm{m}^{-1}$. A germination percentage of $78 \%$ in the control treatment $(0.0$ $\mathrm{dS} \mathrm{m}{ }^{-1}$ ) at $25{ }^{\circ} \mathrm{C}$ was obtained, with a significant decrease until the salinity level of $6.0 \mathrm{dS} \mathrm{m}^{-1}$, and an increase to $80 \%$ of germination at $10.0 \mathrm{dS} \mathrm{m}^{-1}$. Data obtained for seed submitted at the temperature of $30{ }^{\circ} \mathrm{C}$ did not fit to any polynomial regression models and had mean percentage germination of $76 \%$.

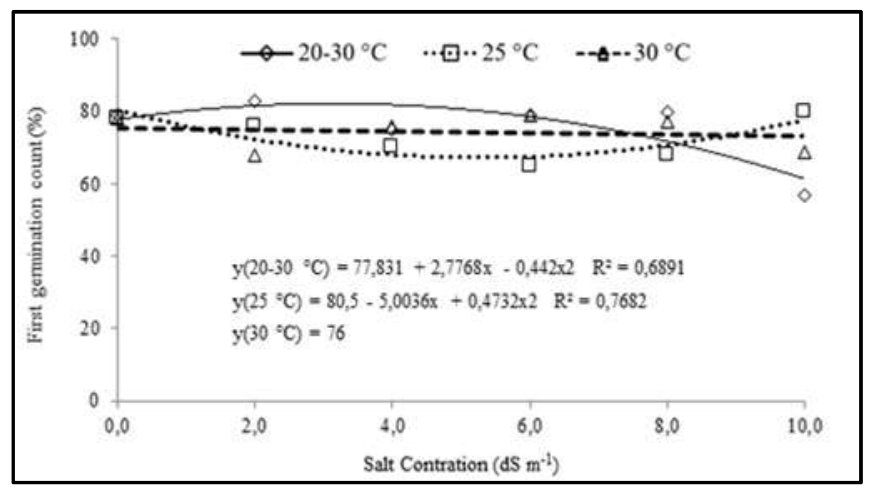

Figure 2. First germination count (\%) of Cajanus cajan (L.) Millspaugh seeds submitted to salt stress at differenttemperatures

The decreases in the germination percentage in the first count with the increasing salinity is probably associated with the physiological drought due to osmotic potential reduction and, consequently, reduced water potential (FANTI; PEREZ, 2004; RIBEIRO; PELACANI, 2006). This impairs the kinetics of water absorption by the seeds (osmotic effect) and also increases the ions concentration in the embryo (toxic effect) to toxic levels (BETONI; SCALON; MUSSURY, 2011). The results of this study differed from those mentioned by Gomes, Almeida, and Takahashi (2015) for Phaseolus vulgaris, in which salt concentrations $(0.0 ;-0.4 ;-0.8 ;-1.2,-1.6$, and $2.0 \mathrm{MPa}$ ) were not sufficient to reduce the germination percentage in the first count, obtaining similar germination percentages to the control treatment. With the increase in saline concentration from 4.5 $\mathrm{dS} \mathrm{m}{ }^{-1}$ to $12.5 \mathrm{dS} \mathrm{m}^{-1}$, there was a decrease in the first germination count of Vigna unguiculata seeds, although the germination percentage remained high (ARAÚJO NETO et al., 2020). The increase in germination percentage of Cajanus cajan seeds, in the first count in the salt concentration of $2.0 \mathrm{dS} \mathrm{m} \mathrm{m}^{-1}$, at $20-30{ }^{\circ} \mathrm{C}$, was probably because the seed may have been benefited by the conditioning osmotic (priming) caused by the addition of salts to the imbibition solution, since the decrease in water potential of the substrate provides a slower and more uniform water entry to the seed tissues, allowing the reorganization of the membrane system, favoring germination (DANTAS; RIBEIRO; ARAGÃO, 2007; MARCOS FILHO, 2015). These results were similar to those obtained by Silva, Grzybowski and Panobiando (2016) for Zea mays seeds in all tested salinity concentrations $\left(0.10 ; 2.70 ; 5.11 ; 7.42\right.$ and $\left.9.60 \mathrm{dS} \mathrm{m}^{-1}\right)$, and by Araújo Neto et al. (2020) for Vigna unguiculata, which at moderate salinity levels $\left(2.5\right.$ and $\left.5.0 \mathrm{dS} \mathrm{m}^{-1}\right)$ observed that the germination was benefited by physiological conditioning, both at 25 ${ }^{\circ} \mathrm{C}$.
The germination speed index was negatively affected by the $\mathrm{NaCl}$ concentration increase. At the alternating temperature of $20-30{ }^{\circ} \mathrm{C}$, a significant linear reduction was observed from 14.15 to 11.64 in the saline concentration of $10.0 \mathrm{dS} \mathrm{m}^{-1}$. At $25{ }^{\circ} \mathrm{C}$, the highest value (14.34) was obtained in the control treatment $\left(0.0 \mathrm{dS} \mathrm{m}^{-1}\right)$; and reduced until up to the concentration of $6.0 \mathrm{dS} \mathrm{m}^{-1}$. At $30^{\circ} \mathrm{C}$, the data obtained did not fit any polynomial regression models, and had a mean value of 13.47 (Figure 3).

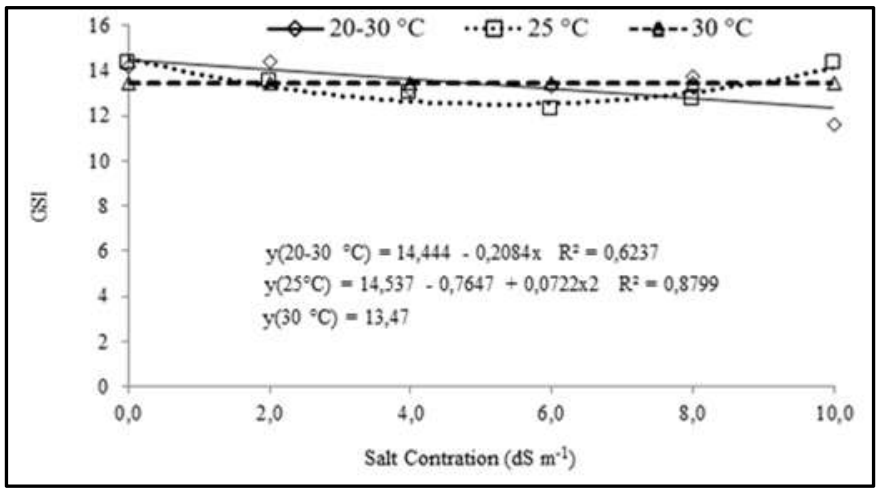

Figure 3. Germination speed index (GSI) of Cajanus cajan (L.) Millspaugh seeds submitted to salt stress at different temperatures

The water stress and the effects caused by salinity can delay seed germination in stages involved in cell division and elongation, mobilization of reserves, consequently affecting the establishment and development of seedlings (MARCOS FILHO, 2015). Germination speed is an essential factor for the rapid establishment of seedlings in the field (DAN et al., 2010) since slow-germination seeds are more exposed to adverse conditions, which can interfere with their establishment (FERREIRA et al., 2013). Seeds with a higher germination speed index show greater performance. Therefore, they have a greater ability to tolerate stresses that may interfere with both plant growth and development (ARAÚJO; MOREIRA; GUEDES, 2019). The primary root length (Figure 4) reduced linearly at $20-30$ and $25{ }^{\circ} \mathrm{C}$. However, at $30{ }^{\circ} \mathrm{C}$, a quadratic behavior was observed with a longer root length $(3.87 \mathrm{~cm})$ in the control treatment $\left(0.0 \mathrm{dS} \mathrm{m}^{-1}\right)$ and a shorter length $(0.62 \mathrm{~cm})$ in the $10.0 \mathrm{dS} \mathrm{m}^{-1}$ salinity level. At $20-30{ }^{\circ} \mathrm{C}$ and salinity level of $2.0 \mathrm{dS} \mathrm{m}^{-1}$, there was an increase in primary root length, followed by decreases in the remaining salinity levels.

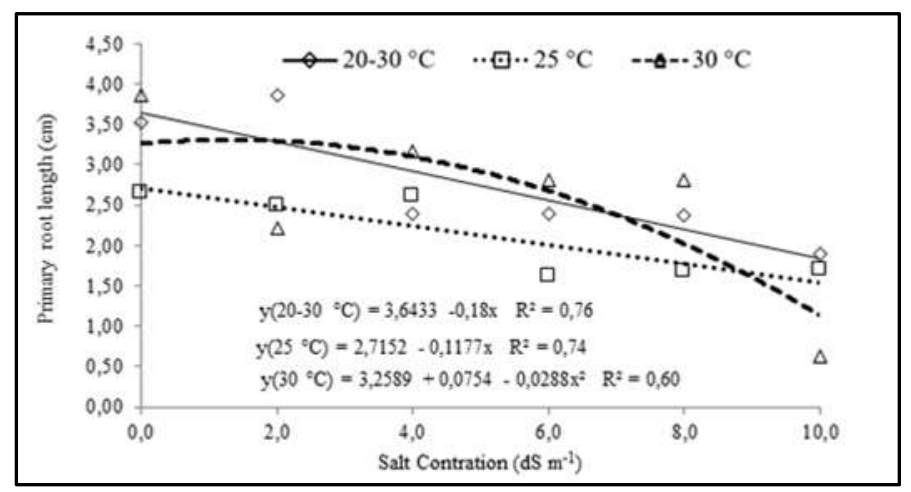

Figure 4. Primary root length (cm) of Cajanus cajan (L.) Millspaugh seedlings submitted to salt stress at different temperatures

The primary root increase at $2.0 \mathrm{dS} \mathrm{m}^{-1}$, and $20-30{ }^{\circ} \mathrm{C}$, can be attributed to osmotic conditioning, as observed for germination, first germination count, and germination speed index, which were benefited by the possible presence of salt in the substrate that ended up controlling the water absorption by the seeds and thus preventing possible damage to the membrane. 
According to Calvet et al. (2013), the salt stress effects on germination and seedling establishment may be related to the environmental effects. The increase in salt concentration causes a reduced osmotic potential in the soil and/or substrate solution, difficulting the water absorption by the seeds and roots and the direct toxic effects caused by specific ions or nutritional disorder caused by impaired absorption of nutrients. The root growth is negatively affected by $\mathrm{NaCl}$ concentrations, with more significant effects at higher salinity levels (CAVALCANTE et al., 2019), a fact observed for Cajanus cajan seedlings in this study. The salt stress effects on root length were also verified for other species, such as Phaseolus Vulgaris, where the shortest root length $(7.49 \mathrm{~cm})$ was observed in the most negative potential of $-2.0 \mathrm{MPa}$, at a $25{ }^{\circ} \mathrm{C}$ (GOMES; ALMEIDA; TAKAHASHI, 2015). A reduced increment in the root structure for Zea mays, observed by the significant reduction in root length at $25{ }^{\circ} \mathrm{C}$ was observed by Silva et al., 2016. The root length of the Clitoria fair childiana seedlings was negatively affected by salinity levels $\left(0.0 ; 1.5 ; 3.0 ; 4.5 ; 6.0 ; 7.5 ; 9.0\right.$ and $\left.10.5 \mathrm{dS} \mathrm{m}^{-1}\right)$ at 25 and $30{ }^{\circ} \mathrm{C}$ and alternating temperatures of $20-30{ }^{\circ} \mathrm{C}$. Data of shoot length of Cajanus cajan seedlings submitted to temperatures of 2030,25 and $30{ }^{\circ} \mathrm{C}$ fitted to the linear regression model. A decrease in shoot length as the salinity level became more negative was observed (Figure 5). The longest shoot length $(4.67$ and $4.52 \mathrm{~cm})$ was obtained in the control treatment $\left(0.0 \mathrm{dS} \mathrm{m}^{-1}\right)$ at 30 and $20-30{ }^{\circ} \mathrm{C}$, respectively. The temperature of $30{ }^{\circ} \mathrm{C}$ promoted the largest shoot length, considered, therefore, the most adequate for development of this species.

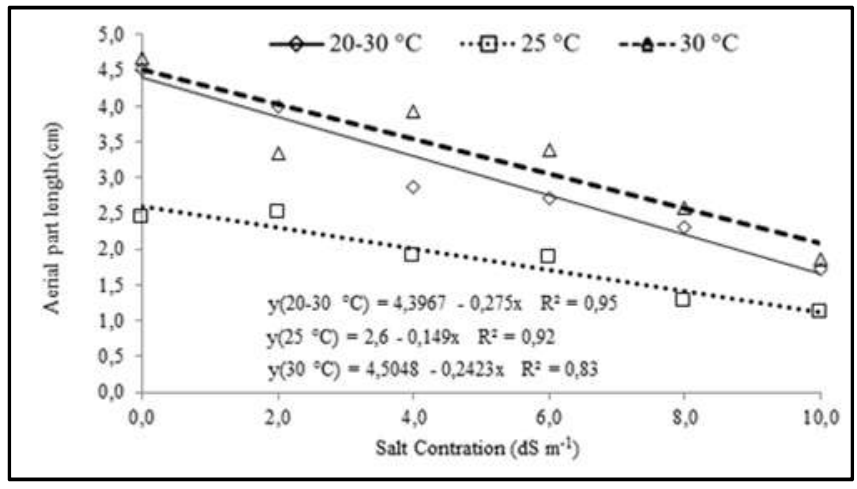

Figure 5. Shoot length of (cm) of Cajanus cajan (L.) Millspaugh seedlings submitted to salt stress at different temperatures

Different results were obtained by Silva, Grzybowski and Panobiando (2016) for shoot length of Zea mays seedlings, with a growth sensitivity in the lowest concentration, followed by a stabilization in the intermediate concentrations and a reduced growth in the higher concentration. Nascimento et al. (2017) found that increased salinity levels also reduced the shoot growth of Phaseolus lunatus seedlings in different levels among the varieties evaluated. Similarly, Araújo Neto et al. (2020) observed that high salinity levels significantly compromised the seedlings length of Vigna unguiculata seedlings more severely than seed germination. Salts excess causes a significant reduction in plant growth, resulting in agriculture losses (CAVALCANTE et al., 2010). These reductions are the first visible salt stress effects due to decreased cell expansion (TAIZ; ZEIGER, 2013). When seedlings are exposed to salt-stress conditions, they might use strategies to overcome stress, such as direct the growth to the aerial parts (SILVA; GRZYBOWSKI; PANOBIANCO, 2016); This probably occurred for the Cajanus cajan seedlings under saltstress conditions, where a more accentuated growth in the shoots was observed in comparison to the primary roots, possibly as a survival strategy. The aerial plant part is responsible for photosynthesis. Its exteriorization on the soil surface is essential before the endosperm reserves are entirely depleted (SILVA; GRZYBOWSKI; PANOBIANCO, 2016). In addition, to shoot and root adverse growth effects, many abnormal Cajanus cajan seedlings were also observed with the increase in salinity. This was probably due to the $\mathrm{NaCl}$ osmotic and toxic effects. These results show that Cajanus cajan is a salinity sensitive crop in the initial growth phase.
The root dry mass of Cajanus cajan seedlings underwent a linear decrease at 20-30 and $25{ }^{\circ} \mathrm{C}$, as the salinity levels increased. However, at $20-30{ }^{\circ} \mathrm{C}$, the roots had the highest dry mass content $(0.011 \mathrm{~g})$. Data of root mass at $30{ }^{\circ} \mathrm{C}$ did not fit any polynomial regression model, with a mean of $0.0080 \mathrm{~g}$. (Figure 6).

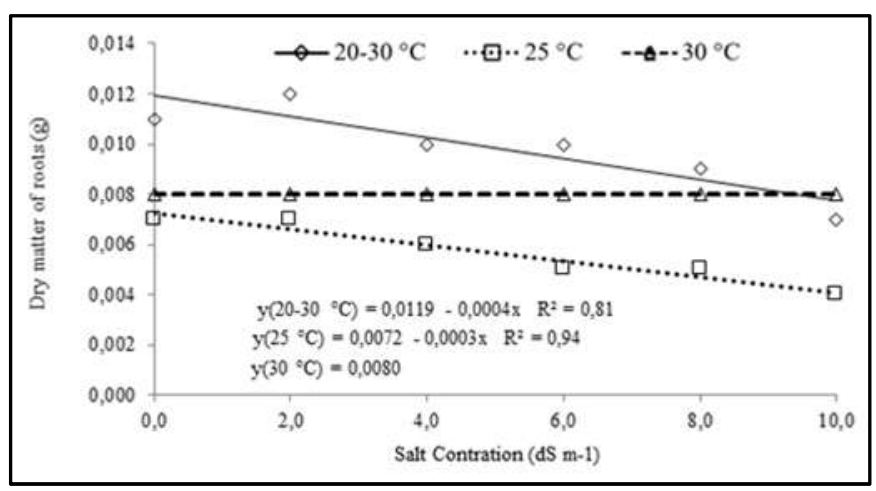

Figure 6. Root dry mass of Cajanus cajan (L.) Millspaugh seedlings submitted to salt stress at different temperatures

The results obtained in this study differ from those obtained by Nascimento et al. (2017) for Phaseolus lunatus, in which the shoot and root dry mass was not affected by the increasing salinity levels $\left(1.5 ; 3.0 ; 4.5 ; 6.0 ; 7.5\right.$ and $\left.9.0 \mathrm{dS} \mathrm{m}^{-1}\right)$. However, a slight variation was observed for the dry mass according to the temperatures $(25,30$ and $35{ }^{\circ} \mathrm{C}$ ) and different varieties. Seedling dry mass is a growth evaluation method through which it is possible to accurately determine the transfer of seed reserve to the embryonic axis so that seedlings with the highest dry mass accumulation are considered the most vigorous (MARTINS; NAKAGAWA; BOVI, 1999). As shown in Figure 7, the shoot dry mass of the Cajanus cajan seedlings suffered a linear decrease at 20-30 and $25^{\circ} \mathrm{C}$, and the highest dry mass $(0.011$ and $0.008 \mathrm{~g})$ obtained in the control treatment $(0.0 \mathrm{dS} \mathrm{m}$ ${ }^{1}$ ), respectively, followed by an accentuated decrease up to the salinity level of $10.0 \mathrm{dS} \mathrm{m}^{-1}$. However, at $30^{\circ} \mathrm{C}$, the dry mass was less affected by the salinity levels, where the highest weight was obtained $(0.013 \mathrm{~g})$ compared to the other temperatures.

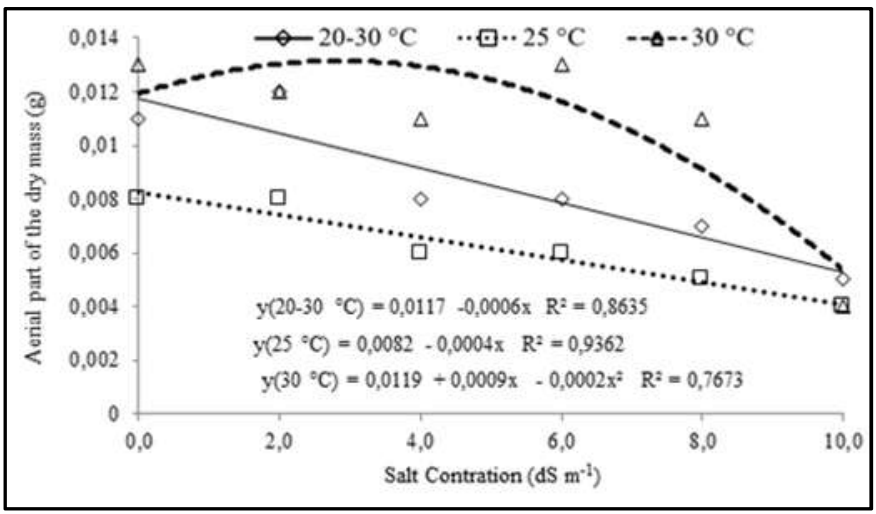

Figure 7. Shoot dry mass (g) of Cajanus cajan (L.) Millspaugh seedlings submitted to salt stress at different temperatures

Similarly, simulated saline stress with irrigation water at different levels also caused decreases in biomass accumulation of Cajanus cajan plants (ARAÚJO; MOREIRA; GUEDES, 2019). However, this effect was not observed for Vigna unguiculata since the moderate salt concentrations ( 4.0 and $4.5 \mathrm{dS} \mathrm{m}^{-1}$ ) contributed to a more significant seedlings dry mass accumulation (1.84 and $2.23 \mathrm{~g}$, respectively) compared to the control treatment (ARAÚJO NETO et al., 2020). It is noteworthy that salinity tolerance varies between species and between varieties/genotypes of the same species, in addition to the plant development stage at the exposure time (DEUNER et al., 2011). Nascimento et al. (2017), evaluating the effect of salt stress on different Phaseolus lunatus varieties at different temperatures, found more sensitive varieties to salt stress at high temperatures and more 
tolerant varieties at high levels of salinity until up to the salinity level of $9.0 \mathrm{dS} \mathrm{m}^{-1}$. Salinity is an uprising concern in arid and semi-arid regions. Therefore, studies with crops cultivated in these regions are essential (NASCIMENTO et al., 2017), aiming to select more tolerant varieties and genotypes that can withstand and produce under moderate or low salt-stressed conditions.

\section{CONCLUSIONS}

The increase in salinity levels reduces the germination and vigor of Cajanus cajan seeds, mainly at $25{ }^{\circ} \mathrm{C}$; Salt stress simulated with $\mathrm{NaCl}$, up to $10.0 \mathrm{dS} \mathrm{m}^{-1}$, does not impair the germination of Cajanus cajan seeds.

\section{REFERENCES}

Almeida, C.S.; Guariz, H.R.; Pinto, M.A.B.; Almeida, M.F. Germination of creole maize and fava bean seed sunder salt stress. Revista Caatinga, Mossoró, v.33, n.3, p.853-859, 2020.

Amorim, J.R.A.; Fernandes, P.D.; Gheyi, H.R.; Azevedo, N.C. Efeito da salinidade e modo de aplicação da água de irrigação no crescimento e produção de alho. Pesquisa Agropecuária Brasileira, Londrina, v.37, n.2, p.167-176, 2002.

Araújo Neto, A.C.; Nunes, R.T.C.; Costa, R.Q.; Moreira, G.L.P.; Silva, R.A.; São José, A.R. Germinação e crescimento inicial de Vigna unguiculata (L.) Walp. sob estresse salino. Revista de Ciências Agrárias, Lisboa, v.43, n.3, p.283-292, 2020.

Araújo, B.A.; Moreira, F.J.C.; Guedes, F.L. Emergência e crescimento inicial de feijão guandu emfunção dos substratos e salinidade da água de irrigação. Revista Agrária Acadêmica, Imperatriz, v.2, n.4, p.90-101, 2019.

Azevedo, R.L.; Ribeiro, G.T.; Azevedo, C.L.L. Feijão guandu: uma planta multiuso. Revista da Fapese, Aracaju, v.3, n.2, p.81-86, 2007.

Betoni, R.; Scalon, S.P.Q.; Mussury, R.M. Salinidade e temperature na germinação e vigor de sementes de mutambo Guazuma ulmifolia Lam.) (Sterculiaceae). Revista Árvore, Viçosa, v.35, n.3, supl.1, p.605-616, 2011.

Brasil. Ministério da Agricultura, Pecuária e Abastecimento. Regras para análise de sementes. Secretaria de Defesa Agropecuária. Brasília: MAPA/ACS, 2009. 395p.

Calvet, A.S.F.; Pinto, C.M.; Lima, R.E.M.; Maia-Joca, R.P.M.; Bezerra, M.A. Crescimento e acumulação de solutos em feijão caupi irrigado com águas de salinidade crescente em diferentes fases de desenvolvimento. Irriga, Botucatu, v.18, n.1, p.148-159, 2013.

Carvalho, N.M.; Nakagawa, J. Sementes: ciência, tecnologia e produção. 5.ed. Jaboticabal: FUNEP, 2012. 590p.

Cavalcante, J.A.; Reolon, F.; Moraes, C.L.; Ternus, R.M.; Silva, R.N.O.; Martins, A.B.N.; Moraes, D.M. Potencial fisiológico de sementes de duas cultivares de arroz em resposta ao estresse salino. Revista de Ciências Agrárias, Lisboa, v.42, n.1, p.184193, 2019.

Cavalcante, L.F.; Cordeiro, J.C.; Nascimento, J.A.M.; Cavalcante, I.H.L.; Dias, T.J. Fontes e níveis da salinidade da água na formação de mudas de mamoeiro cv. sunrise solo. Semina: Ciências Agrárias, Londrina, v.31, n.4, sup.1, p.1281-1290, 2010.

Coelho, D.L.M.; Agostini, E.A.T.; Guaberto, L.M.; Machado Neto, N.B.; Custódio, C.C. Estresse hídrico com diferentes osmóticos em sementes de feijão e expressão diferencial de proteínas durante a germinação. Acta Scientiarum. Agronomy, Maringá, v.32, n.3, p.491-499, 2010.

Dan, L.G.M.; Dan, H.A.; Barroso, A.L.L.; Braccini, A.L. Qualidade fisiológica de sementes de soja tratadas com inseticidas sob efeito do armazenamento. Revista Brasileira de Sementes, Londrina, v.32, n.2, p.131-139, 2010.

Dantas, B.F.; Ribeiro, L.S.; Aragão, C.A. Germination, initial growth and cotyledon protein content of bean cultivars under salinity stress. Revista Brasileira de Sementes, Londrina, v.29, n.2, p.106-110, 2007.

Deuner, C.; Maia, M.S.; Deuner, S.; Almeida, A.S.; Meneghello, G.E. Viabilidade e atividade antioxidante de sementes de genótipos de feijão-miúdo submetidos ao estresse. Revista Brasileira de Sementes, Londrina, v.33, n.4, p.711-720, 2011.

Fanti, S.C.; Perez, S.C.J.G.A. Processo germinativo de sementes de paineira sob estresses hídrico e salino. Pesquisa Agropecuária Brasileira, Brasília, v.39, n.9, p.903-909, 2004.

Ferreira, D.F. SISVAR. Sistema para análise de variância. Lavras: UFL/DEX, 2000, CD-ROM

Ferreira, E.G.B.S.; Matos, V.P.; Sena, L.H.M.; Oliveira, R.G.O.; Sales, A.G.F.A. Processo germinativo e vigor de sementes de Cedrela odorata L. sob estresse salino. Ciência Florestal, Santa Maria, v.23, n.1, p.99-105, 2013.

Freire, M. B. G. S.; Freire, F. J. Fertilidade do solo e seu manejo em solos afetados por sais. In: Novais, R. F.; et al. (ed.). Fertilidade do solo. Viçosa: Sociedade Brasileira de Ciência do Solo. 2007. 929-954p.

Gomes, G.R.; Almeida, L.H.C.; Takahashi, L.S.A. Efeito do estresse hídrico e salino no vigor e germinação de sementes de feijãovagem (Phaseolus vulgaris L.). Cultura Agronômica, Ilha Solteira, v.24, n.1, p.83-92, 2015.

Lopes, J.C.; Macedo, C.M.P. Germinação de sementes de couve chinesa sob influência do teor de água, substrato e estresse salino. Revista Brasileira de Sementes, Londrina, v.30, n.3, p. 079-085, 2008.

Maguire, J.D. Speed of germination aid in selection and evaluation of seedling emergence and vigor. Crop Science, Madson, v.2, n.2, p.176-177, 1962.

Marcos Filho, J. Fisiologia de sementes de plantas cultivadas. 2.ed. Piracicaba: FEALQ, 2015. 660p.

Martins, C.C.; Nakagawa, J.; Bovi, M.L.A. Efeito da posição da semente no substrato e no crescimento inicial das plântulas de palmito-vermelho (Euterpe espirito santensis Fernandes Palmae). Revista Brasileira de Sementes, Londrina, v.21, n.1, p.164-173, 1999.

Matias, J.R.; Torres, S.B.; Freire, J.N.T.; Alencar, S.S.; Dantas, B.F. Germinação de sementes de Cenostigma pyramidales ob diferentes temperaturas e salinidades. Informativo Abrates, Londrina, v.28, n.1, p.115-118, 2018.

Nascimento, M.G.R.; Alves, E.U.; Silva, M.L.M.; Rodrigues, C.M. Lima Bean (Phaseolus lunatus L.) seeds exposed to different salt concentrations and temperatures. Revista Caatinga, Mossoró, v.30, n.3, p.738-747, 2017.

Nene, Y.L.; Sheila, V.K. Pigeonpea: geographya nd importance. In: Nene, Y.L.; Hall, S.D.; Sheila, V.K (Eds.). The pigeonpea. Cambridge: CAB International/ICRISAT, 1990.1-14p.

Pelegrini, L.L.; Borcioni, E.; Nogueira, A.C.; Koehler, H.S.; Quiorin, M.G.G. Efeito do estresse hídrico simulado com $\mathrm{NaCl}$, manitol e PEG (6000) nagerminação de sementes de Erythrina falcata Benth. Revista Ciência Florestal, Santa Maria, v.23, n.2, p.511519, 2013.

Pereira, F.A.L.; Medeiros, J.F.; Gheyi, H.R.; Dias, N.S.; Preston, W.; Vasconcelos, C.B.L. Tolerance of melon cultivars to irrigation water salinity. Revista Brasileira de Engenharia Agrícola e Ambiental, Campina Grande, v.21, n.12, p.846-851, 2017.

Rufini, M. Oliveira, D.P.; Trochmann, A.;Soares, B.L.; Andrade, M.J.B.; Moreira, F.M.S. Estirpes de Bradyrhizobium em simbiose com guandu anão em casa de vegetação e no campo. Pesquisa Agropecuária Brasileira, Brasília, v.49, n.3, p.197-206, 2014.

Santos, C.A.F. Guandu Petrolina: opção na produção de grãos para a agricultura familiar. Petrolina, EMBRAPA/CPATSA, 2000. 6p. (Instruções Técnicas, 46).

Silva, R.C.; Grzybowski, C.R.S.; Panobianco, M. Vigor de sementes de milho: influência no desenvolvimento de plântulas em condições de estresse salino. Revista Ciência Agronômica, Fortaleza, v.47, n.3, p.491-499, 2016.

Silva, D.C.; Alves, E.U.; Santos-Moura, S.S.; Ursulino, M.M.; Araújo, L.R. Estresse salino e diferentes temperaturas alteram a 
fisiologia em sementes de Clitoria fairchildiana Howard. Ciência Florestal, Santa Maria, v.29, n.3, p.1129-1141, 2019.

Soares, M.M.; Santos Júnior, H.C.; Simões, M.G.; Pazzin, D.; Silva, L.J. Estresse hídrico e salino em sementes de soja classificadas em diferentes tamanhos. Pesquisa Agropecuária Tropical, Goiânia, v.45, n.4, p.370-378, 2015.

Souza, E.M.; Alves, E.U.; Silva, M.L.M.; Araújo, L.R.; Santos Neta, M.M.S. Substrate moisture and temperature in Cajanus cajan (L.) Millspaugh germination. Semina: Ciências Agrárias, Londrina, v.38, n.4, sup.1, p.2375-2386, 2017.
Taiz, L.; Zeiger, E. Fisiologia Vegetal. $5^{\mathrm{a}}$ ed. Porto Alegre, Artmed, 954 p. 2013

Tayyab; Azeem, M.; Qasim, M.; Ahmed, N.; Ahmad, R. Salt stress responses of pigeonpea (Cajanus cajan) on growth, yield and some biochemical attributes. Pakistan Journal Botany, Karachi, v.48, n.4, p.1353-1360, 2016. 